This document is the accepted manuscript version of the following article:

Ross, K. A., Smets, B., De Batist, M., Hilbe, M., Schmid, M., \& Anselmetti, F. S. (2014). Lake-1eve1 rise in the late Pleistocene and active subaquatic volcanism since the Holocene in Lake Kivu, East

African Rift. Geomorphology, 221, 274-285. https://doi.org/10.1016/j.geomorph.2014.05.010

This manuscript version is made available under the CC-BY-NC-ND 4.0 1icense http://creativecommons.org/ 1icenses/by-nc-nd/4.0/

\title{
Lake-level rise in the late Pleistocene and active subaquatic volcanism since the Holocene in Lake Kivu; East African Rift
}

\author{
Kelly Ann Ross ${ }^{\mathrm{a}, \mathrm{b}, *}$, Benoît Smets ${ }^{\mathrm{c}, \mathrm{d}, \mathrm{e}}$, Marc De Batist ${ }^{\mathrm{f}}$, Michael Hilbe ${ }^{\mathrm{a}, \mathrm{b}, \mathrm{g}}$, \\ Martin Schmid $^{a}$, Flavio S. Anselmetti ${ }^{\mathrm{g}}$ \\ ${ }^{a}$ Department of Surface Waters Research and Management, Eawag: Swiss Federal \\ Institute of Aquatic Science and Technology, Switzerland \\ ${ }^{b}$ Institute of Biogeochemistry and Pollutant Dynamics, ETH: Swiss Federal Institute of \\ Technology, Switzerland \\ ${ }^{c}$ European Center for Geodynamics and Seismology, Luxembourg \\ ${ }^{d}$ Department of Geography, Vrije Universiteit Brussel, Belgium \\ ${ }^{e}$ Department of Earth Sciences, Royal Museum for Central Africa, Belgium \\ ${ }^{f}$ Renard Centre of Marine Geology, Department of Geology and Soil Science, Ghent \\ University, Belgium \\ ${ }^{g}$ Institute of Geological Sciences and Oeschger Centre for Climate Change Research, \\ University of Bern, Switzerland
}

\begin{abstract}
The history of Lake Kivu is strongly linked to the activity of the Virunga volcanoes. Subaerial and subaquatic volcanoes, in addition to lake-level changes, shape the subaquatic morphologic and structural features in Lake Kivu's Main Basin. Previous studies revealed that volcanic eruptions blocked the former outlet of the lake to the north in the late Pleistocene, leading to a substantial rise in the lake level and subsequently the present-day thermohaline stratification. Additional studies have speculated that volcanic and seismic activity threaten to trigger a catastrophic release of the large amount of gases dissolved in the lake. A bathymetric mapping and seismic profiling survey covered the volcanically active area of the Main Basin at a high resolution unprecedented for Lake Kivu. New geomorphologic features identified on the lake floor can accurately describe related lake-floor processes for the first time. The late Pleistocene lowstand is observed at $425 \mathrm{~m}$ depth, and
\end{abstract}

\footnotetext{
*Ph. +41 (0)774031659

Email address: kellyann.ross@gmail.com (Kelly Ann Ross )
} 
volcanic cones, tuff rings, and lava flows observed above this level indicate both subaerial and subaquatic volcanic activity during the Holocene. The geomorphologic analysis yields new implications on the geologic processes that have shaped Lake Kivu's basin, and the presence of young volcanic features can be linked to the possibility of a lake overturn.

Keywords:

rift lake, lake-level rise, subaquatic volcano, subaquatic lava flow, limnic eruption, high-resolution bathymetry

\section{Introduction}

Together with Lakes Nyos and Monoun in Cameroon, Lake Kivu is reputed for being one of the three 'exploding lakes' in Africa (Halbwachs et al. 2004; Kling et al., 1987). Lakes Monoun and Nyos erupted in the 1980s resulting in nearly 2000 fatalities. A limnic eruption, commonly referred to as a lake 'explosion', is a result of oversaturation of dissolved gases that accumulate in the stratified depths of the lake. Lake Kivu's large size and population density extends the risk of a limnic eruption to millions of people. The lake's permanently stratified deepwater contains vast quantities of dissolved $\mathrm{CO}_{2}$; $300 \mathrm{~km}^{3}$ at STP (standard temperature and pressure), and $\mathrm{CH}_{4} ; 60 \mathrm{~km}^{3}$ at STP (Schmid et al., 2005). These gases would erupt from the stratified depths, and consequently mix the lake, if their combined partial pressures were to exceed the hydrostatic pressure of the lake at all depths (Schmid et al., 2005). The $\mathrm{CO}_{2}$ is a product of magmatism and active volcanism in the lake basin (Degens et al., 1973; Tedesco et al., 2010), whereas the $\mathrm{CH}_{4}$ is produced by microbial activity in the anoxic sediment (Tietze et al., 1980; Pasche et al., 2011; Bhattarai et al., 2012). $\mathrm{CO}_{2}$ and $\mathrm{CH}_{4}$ gas accumulate in the deepwater below the main density gradient centred at $255 \mathrm{~m}$ depth. This gradient is sustained by fresh groundwater inputs from above, and salt and $\mathrm{CO}_{2}$ entering with hydrothermal inputs at greater depths (Schmid et al. 2005; Ross et al., 2014).

Volcanic activity has played an important role in the evolution of Lake Kivu, especially that within the Virunga Volcanic Province (VVP) (e.g., Smets et al., 2010b; d'Oreye et al., 2011). The cities Goma (DRC; the Democratic Republic of Congo) and Gisenyi (Rwanda), located on the northern shoreline of the lake (Figure 1), are constructed almost entirely on lava flows. Furthermore, the presence of phreatomagmatic cones along the north- 
ern shoreline document the historical occurrences of eruptive events at the lake boundary (Capaccioni et al., 2003). Haberyan and Hecky (1987) estimated that Lake Kivu's northern outflow to Lake Edward was dammed by the lavas of the VVP sometime in the late Pleistocene. This blockage was followed by lake-level rise that eventually drained south along a border fault to Lake Tanganyika at $~ 10-14$ ka, which is occupied by the present-day 'Ruzizi River' in Figure 1 (Degens et al., 1973).

Several studies have been made on the sediments of Lake Kivu and Lake Tanganyika that date the geological developments contributing to the current state of Lake Kivu. An overview of the proposed events is given from the varying data in the publications, and summarized in Table 1. Core dating on the sediment taken by Degens et al. (1973) in the 1970s was based on radiocarbon measurements of bulk organic carbon, and therefore could be anomalously old due to hydrothermal inputs of $\mathrm{CO}_{2}$. In summary, Lake Kivu's stratification (state of meromixis) was initiated with its lake-level rise at $\sim 10-14$ ka (Table 1). Its alteration from a thermal to a thermohaline stratification was inferred to have been initiated within the last 6 kyrs according to Hecky and Degens (1973). The researchers postulated that the change was presented with the onset of hydrothermal spring activity within the stratified depths of the lake (Degens and Kulbicki, 1973). At least two periods are described in literature where there has been a breakdown of the thermohaline stratification linked to intense hydrothermal activity from volcanism within the last 6 kyrs (Table 1). Recent acquisition of sediment cores, and radiocarbon dating at subaquatic-tephra layers in Lake Kivu have determined a date of $\sim 0.8$ ka for the last lake-overturn event. Ongoing hydrothermal spring inputs into the deepwater of the main basin were identified based on data obtained by CTD (conductivity, temperature, and depth) profiling (Ross et al., 2014). The lack of knowledge of the lake-floor processes relating to hydrothermal spring activity were the motivation to produce the high-resolution bathymetric map and seismic profiles that are presented here.

The newly constructed map of the Main Basin delineates the geomorphology in Lake Kivu at a resolution that is unprecedented for African rift lakes. Furthermore, our dataset represents the first high-resolution geophysical analysis on the sediment. The Main Basin hosts a variety of geologic structures and processes including: lava flows (e.g., Halbwachs et al., 2004; Komorowski, 2003), faults/fractures (e.g., Peeters, 1957; Degens et al., 1973 ; Wong and von Herzen, 1974), hydrothermal vents (Degens and Kulbicki, 1973; Schmid et al., 2005: Tassi et al., 2009), earthquake epicentres (e.g., 


\begin{abstract}
Kavotha et al., 2003; Wong and von Herzen, 1974; d'Oreye et al., 2011; Mavonga et al., 2006, 2010), and dike/magma intrusions (Wauthier et al. 2010, 2012). Volcanic and seismic activities have significantly affected Lake Kivu, but the question concerning the possibility of a lake overturn and expulsion of gas triggered by volcano-tectonic activity remains debated. There is no historical documentation of an event causing a lake overturn, and the last overturn is thought to have occurred at $\sim 0.8$ ka (Table 1). Here we discuss new and crucial insights into the development of Lake Kivu's basin, which are interpreted from the lake-floor processes that shape its geomorphology. The unprecedented look into Lake Kivu's sublacustrine environment provides a more accurate assessment of its current geologic state, with implications for the possibility of a lake overturn event as a result of subaquatic volcanic activity.
\end{abstract}

\title{
2. Geological setting of the Lake Kivu basin
}

\subsection{Location and morphology}

Lake Kivu, shared by the Democratic Republic of Congo (DRC) and the Republic of Rwanda (Rwanda) (Figure 1), is a rift lake in the Western Rift branch of the East African Rift system (EARS). The EARS is an intracontinental region of lithospheric extension and is volcanically and seismically active (Ebinger, 1989). Most of the African great lakes sit within the EARS, with the exception of Lake Victoria. The Western Rift branch is a seismically active corridor that encircles the Archaean Tanzania craton (Ebinger, 1989) and extends from Lake Albert in the north to Lake Malawi in the south. The different rift basins that make up the Western Rift branch are separated from each other by accommodation zones (Ebinger, 1989). Lake Kivu is centred on the rift axis and is the highest of the western rift lakes, located at an altitude of $1463 \mathrm{~m}$ asl (e.g., Degens et al., 1973). It has a surface area of $2386 \mathrm{~km}^{2}$, a volume of $549 \mathrm{~km}^{3}$, and is $486 \mathrm{~m}$ in depth. The irregular shoreline of Lake Kivu strongly differs from the other rift lakes in the western branch of the EARS. The rift lakes generally present smoother and elongated shapes that reflect the strong control of rift-basin border faults on their morphology. Affirmation of the lake damming in the north is apparent from the orientation of the paleo-hydrographic network, including the lake depth that increases from the south to the north (Boutakoff, 1939).

The present-day lake comprises the Main Basin, consisting of two halfgraben valleys separated by the Idjwi Island horst, and four smaller basins 
(Figure 1): Kabuno Bay, Kalehe Basin, Bukavu Bay, and the Ishungu Basin (Schmid and Wüest, 2012). The Main Basin is filled with a maximum sediment accumulation of $\sim 1.5 \mathrm{~km}$ at the west side of the basin (Wood, 2014). Studies correlating sedimentation rates with seismic stratigraphy in the Main Basin have calculated the age of Lake Kivu to be between the mid-Pleistocene (Haberyan and Hecky, 1987) and the Pliocene (Degens et al., 1973). However, recent research along the eastern half graben of the Main Basin has revealed thicker sediments (Wood, 2014), which might extend Lake Kivu's development to the Miocene.

\subsection{Volcanic and seismic activity}

Four volcanic regions constitute the Western Rift branch including the VVP. The volcanic activity in the VVP dates back to the mid-Miocene, but a majority of the volcanic edifices are expected to be younger than $100 \mathrm{ka}$ BP (Rogers et al., 1998). The VVP is situated in a transfer zone characterized by several fault and fissure networks with different orientations. The main volcanic edifices are located at the intersection of these networks. Nyamulagira and Nyiragongo (Figure 1), are the two currently active volcanoes of the VVP and are distinguished by their effusive eruptions of lava flows and fountains. The cone and eruptive fissure distributions in the Nyamulagira and Nyiragongo volcanic fields generally coincide with the NE and NNWtrending fracture networks of the VVP. The silica-undersaturated composition of their lava yields low viscosities and induces high-velocity flows (e.g., Tazieff, 1977). As a consequence, their lava flows are thin and typically extend tens of kilometres away from the source vent. Nyamulagira is Africa's most active volcano with eruptions every 1-4 years (Smets et al., 2010a). Its lava field covers a surface area of over $1100 \mathrm{~km}^{2}$ and contains more than 100 flank cones. Nyiragongo is permanently active and hosts an active lava lake in its main crater. The last two fissural eruptions in 1977 and 2002 induced a draining of the lava lake. The 2002 eruption of Nyiragongo is hypothesized to be a result of rift tectonics on the basis of isotopic analysis of lava flows (Komorowski, 2003) and ground deformation modeling (Wauthier et al., 2010, 2012). A best-fit model to explain the co-eruptive ground deformations was produced by Wauthier et al. (2012), and suggests the intrusion of a deep dyke extending southward beneath Lake Kivu.

In addition to volcanic activity, the Western Rift branch of the EARS is also defined by significant seismic activity. Herrincks (1959) listed $\sim 800$ seismic events in the period between 1909 and 1954 in DRC, Rwanda, and 
Burundi. The 2002 eruption of Nyiragongo occurred with several pre- co- and post-eruptive earthquakes. Altogether, more than 100 tectonic earthquakes of $\mathrm{M} \geq 3.5$ were recorded on the southern flank of Nyiragongo and in the northern part of Lake Kivu. The most recent and fatal Bukavu-Cyangungu (M 5.9) earthquake in February 2008 had a deleterious impact on infrastructure and triggered landslides in the area (d'Oreye et al., 2011).

The volcanic and seismic events that have been recorded within Lake Kivu have not been conducive to a limnic eruption at the current state of dissolved $\mathrm{CO}_{2}$ and $\mathrm{CH}_{4}$ in the stratified layer. The 2002 eruption of Nyiragongo induced lava flows that extended up to $100 \mathrm{~m}$ deep into Lake Kivu. It was concluded that water temperatures were altered only at a local scale (Lorke et al., 2004), i.e. without any threat to the lake stability. Similar conclusions were reached for the 1938-40 eruption of the neighbouring Nyamulagira, where lava flows entered Kabuno Bay (Verhoogen, 1948). However, the possible consequence of an eruption or a mass movement from within the deepwater of the lake remains more difficult to elucidate.

\section{Data acquisition and analysis}

Bathymetric mapping of Lake Kivu's Main Basin was conducted with a $50 \mathrm{kHz}$ swath system (SeaBeam 1050) in October 2010 over an area of 224 $\mathrm{km}^{2}$ and in water depths from 8 to $486 \mathrm{~m}$ (Figure 2a). Depths given in the analysis and interpretation here within refer to water depth relative to the present-day lake level. The map survey covered the area of the basin known to host most of the geological activity as mentioned in the introduction. The surveying system was mounted to the hull of the boat RV Gloria, and a bathymetric sounding was derived for each beam with up to 126 receive-beams at $120^{\circ}$ athwartship swath. The survey was conducted at an average speed of $2 \mathrm{~m} / \mathrm{s}$ during daylight hours. Positions were provided by a dual-differential GPS-aided inertial navigation system. Boat movements were compensated by a OCTANS 3000 motion sensor. Sound velocity profiles were determined as a function of water density, which was calculated as a function of temperature and salinity using the Chen-Millero equation (Chen and Millero, 1986). Temperature and salinity parameters were acquired via CTD profiling with a RBR ${ }^{\circledR}$ XR-620 probe. The sound velocity at the transducer head was measured continuously for accurate beam-steering. Data acquisition was managed with Hydrostar Online, and HDP was used for post processing and calibration. Data was exported as gridded xyz data from HDP and spikes 
were removed with Fledermaus (version 7) for final editing. In the deeper part of the basin, typically at depths greater than $300 \mathrm{~m}$, the sediment is characterized by a layer of low amplitude reflections at the sediment-water interface that are thought to represent highly water-saturated sediments. E.g. Figure 5, Figure 6, and Ross et al. (2013). The final processing of the bathymetric data was limited by the beam penetrating this layer on occasion, which produced a pronounced grain in the bathymetric map upon interpolation. This is particularly evident at the locations of the outer beams where the angle of incidence is the highest.

Visualization for the analysis of the merged data sets was conducted with GMT 4.5.8 using the functions described within Wessel and Smith (1991). The multibeam data were averaged using the blockmean function onto $5 \mathrm{~m}$ grid spacing and then surface interpolation was conducted using the nearneighbour algorithm on 5 and $10 \mathrm{~m}$ grids. For the geomorphologic interpretation of the bathymetry, the 5 and $10 \mathrm{~m}$ interpolated data was evaluated. A slope angle map was produced from the $10 \mathrm{~m}$ interpolated grid using the grdgradient and grdmath functions to depict the first derivative of the bathymetric data. Depth contours helped to highlight vertical steps at the scale of the basin, and were determined using the function grdcontour. Profile curvatures, defined as the degree of vertical convexity (negative values) or concavity (positive values) of the relief along the line of maximum slope were extracted from the bathymetric map using the DEM (Digital Elevation Model) Surface Tools developed by Jenness (2012) and the Spatial Analyst Extension for the ESRI ArcGIS ${ }^{\circledR}$ software. Both slope and profile curvatures highlight the horizontal limits of specific relief features such as fault escarpments, volcanic cones, landslides, and terraces. The function grdimage was used to produce the planar views of the interpolated 5 and $10 \mathrm{~m}$ grids following the application of an averaging filter using the function grdfilter. Finally, a combined bathymetric map was produced using a low-resolution bathymetric map provided by Lahmeyer (1998), the present-day lake level contour extracted from the $30 \mathrm{~m}$ ASTER Global DEM (GDEM) provided by NASA, and by applying the function grdblend. The result was used to calculate the area and volume at different depth contours for interpretation.

Cross-sectional analysis of the lake-floor subsurface was conducted from high-resolution 2D reflection seismic data of the sediment fill. A $3.5 \mathrm{kHz}$ pinger single-channel system was used to digitally record data of the shallow subsurface down to $\sim 10 \mathrm{~m}$ depth in SEG-Y format with a flat gain. Processing involved bandpass filtering (1600-6000 Hz) and a constant-velocity 
migration for selected areas. Seismic data were interpreted in Kingdom Suite Software.

Temperature anomalies from a background lake-temperature profile were investigated to discern hydrothermal and cold groundwater inflows into Lake Kivu (Ross et al., 2014). Locations where the most significant temperature differences from the background profile were observed, over specific depth ranges, are marked on the bathymetric map. The location of groundwater discharge relative to the local morphology was interpreted to help conclude possible geologic features.

\section{Morphologic and Stratigraphic Analysis}

The bathymetric map covers approximately a tenth of the area of Lake Kivu (Figure 1). The area is subdivided into three regions in order to describe the various geologic features and structures based on their specific geomorphological characteristics (Figure 2a). Geologic features are defined within the limits of resolution and detail determined by the data, and in the context of their volcanic and lacustrine setting. Generally, the morphology in Lake Kivu's Main Basin is shaped by hummocky volcanic relief in the north and northwest regions; Precambrian rocks extending from the shore into the basin from the Mbuzi Peninsula, the Idjwi Island horst, and the drowned river valleys; and enhanced sediment deposition covering deltaic regions, and the flatter regions of the deep basin (Figure 2b). Furthermore, many of these features are demarcated by four depth contours delineated in Figure $2 \mathrm{~b}$. The $425 \mathrm{~m}$ contour outlines the base of the isolated volcanic features, and the extension of the Ijdwi Island horst in the south. The $395 \mathrm{~m}$ contour outlines the base of the volcanic platform in the northwest, and the eroded river valleys in the east. Lastly, the 315 and $250 \mathrm{~m}$ contours outline the base of the steeply sloped walls at the northern limit of Mount Goma, and the tuff rings and maars in the volcanic region.

\subsection{Region 1}

Region 1 (Figure 3) is characterized by the southward extension of the VVP and is dominated in general by volcanic features. Numerous cones, tuff rings and maars, and areas of hydrothermal and cold groundwater discharge distinguish this region (Figure 3). A concentrated area of cones is outlined in Figure 3, with the larger of these features marked as 'small cones' on the map. The numerous maars or tuff rings are recognized by circle-shaped 
crater-rims excavated into the sediment, and flat internal floors with rims built above the sediment, respectively (Figure 3). These features align in the same NE-SW orientation as the 'satellite cones' (Figure 3) linked to the Nyiragongo volcano. This linkage suggests their eruption to have occurred along a similar fault lineament. A large phreatomagmatic satellite cone, Mount Goma, is found at the eastern limit of Figure 3. Mount Goma's steep walled summit crater is used as a port for the city of Goma, whereas its main edifice is submerged and gently sloped. A total of three prominent subaquatic volcanic features are distinguished in Region 1: the first is a broad dome found south of the concentrated cones and surrounded by maars and tuff rings ('A' on Figure 4a); the second feature is the apparent lava flow located just south of this cone ('B' on Figure 4a); and the third is the cone directly west of Mount Goma, which lacks a summit crater ('C' on Figure 4a). In addition to the volcanic features, areas of concentrated groundwater inflows are observed in, and are specific to Region 1. Hydrothermal groundwater is observed in the area dominated by the maars/tuff rings and small cones, whereas cool groundwater flows can be found where the limit of the Mount Goma edifice abuts the steeply sloped wall to the northwest. Groundwater flows are likely discharged from high-velocity conduits, such as faults and fractures, that are not visible at the resolution of the map. Region 1 is further divided into frames i to iii to describe geologic features.

\subsubsection{Frame $i$}

The volcanic field in Frame $\mathrm{i}$ is linked to the southern extension of the phreatomagmatic cones of the Bulengo-Rusayo zone (d'Oreye et al., 2011). The most striking feature in Frame i is a $\sim 3 \mathrm{~km}$ wide and $\sim 200 \mathrm{~m}$ high dome that cuts the NE-SW alignment of maars and tuff rings ('A' on Figure 4a i). The slopes of the dome are on the order of 3 to $12^{\circ}$ and appear smooth and constructional. Furthermore, the dome appears to be superimposed onto tuff rings on its western and eastern margin, indicating that the dome is younger than these features. The smooth lobes to the southeast are separated from the dome by a small valley, and the base of the dome disappears where the lobes terminate at $\sim 395 \mathrm{~m}$ depth. The dome-like characteristic implies that it has a magmatic origin and could indicate a subaquatic volcanic eruption. However, there are no distinct morphologic traits to suggest that the dome was formed either as a subaquatic or subaerial feature.

The northern part of Frame i is composed of several grouped, or aligned, cones with diameters ranging from 10 to $100 \mathrm{~m}$ ('small volcanic cone' on 
Figure 3). These features are interpreted to be created by the explosive interaction of lava and water-saturated sediment, defined as rootless cones by Hamilton et al. (2010). The cones are built over a large and irregular plateau, which likely corresponds to lava flows with fronts ending at a depth of $\sim 250 \mathrm{~m}$ (Figure 4a i). Additional rootless cones can be seen in the concentrated area marked in Figure 3, which reach the dome and maar features in the map to depths of $315 \mathrm{~m}$. The cones observed deeper than the $250 \mathrm{~m}$ contour are likely formed from older lava flows that were covered by subsequent sedimentation.

The maars and tuff rings located in Frame i are outlined at the base of their external flanks by both the 250 and $315 \mathrm{~m}$ contour (Figure 4a i). Maars, tuff rings, and phreatomagmatic edifices are created by the explosive interaction between lava and the groundwater aquifer or surface water (Zimanowski and Büttner, 2003). The wide and shallow morphology of the maars and the presence of tuff rings are indicative of shallow-water steam explosions (Lorenz, 1986). Consequently, we can assume a lake level equivalent to the $\sim 315$ and $250 \mathrm{~m}$ contours at the time of their formation. The high-resolution seismic profiles of the tuff rings along profile S3 and in the northeast corner in Figure 5 (seismic profile not shown) reveals layered sediments reaching an average depth of $4.2 \mathrm{~m}$ (std. dev. 1.1). The sedimentation in the crater is absent of unconformities and is assumed to be subsequent to the tuff formations and lake-level rise, i.e., eliminating the possibility of erosion, volcanic sediment accumulation, and isolated lakes (Figure 5 S3). Using the sedimentation rates of $30 \mathrm{~cm}$ per 1000 yrs calculated by Degens et al. (1973), we can assume their formation to be $\sim 14 \mathrm{ka}$. This is a rough estimate of age, where recent sedimentation rates of up to $46 \mathrm{~cm}$ per 1000 yrs calculated by Ross et al. (2013) would yield an age of $\sim 9$ ka.

The terraces observed in the seismic sections in Frame i along profiles $\mathrm{S} 1$ and S2 are interpreted as paleoshore indicators, yielding evidence to the possibility of a lake-level rise that would have submerged the tuff rings. The terraces are on average 100 to $200 \mathrm{~m}$ across with heights of 5 to $10 \mathrm{~m}$ Figure 5 S1 and S2). The horizontal alignment of the terraces between profiles S1 and S2 imply a lake-level transgression from the $\sim 425$ to $395 \mathrm{~m}$ contour. The presence of lake-level indicators has been observed in the seismic profiles of Lake Edward and Lake Malawi, although they represent delta progradation controlled by climatically-induced lake-level changes that are not comparable to the seismic facies observed here (McGlue et al., 2006; Lyons et al., 2011). However, studies from other large lakes documented paleoshoreline terraces of equal dimensions formed by 'in-place drowning' of beach ridges, 
and formation of a new ridge at landward positions from rapid water-level rises (Gilli et al., 2005). An alternative theory is that the terraces are a product of block faulting in the lake. This would require fault lineaments in the N-S to NE-SW orientation, which aligns to the maars and tuff rings in the lake and to faults (e.g., Ebinger, 1989) and eruptive fissures observed onshore.

\subsubsection{Frame ii}

Mount Goma is a polygenetic, phreatomagmatic volcanic cone (Denaeyer, 1975) consisting of an emerged steep summit crater and a submerged gentle sloping flank (Figure 4a ii). The summit of the volcano is composed of relatively recent ash deposits overlying at least two series of tuff layers (Denaeyer, 1975). The 2 to $10^{\circ}$ slopes of the subaquatic flank of Mount Goma are characterized by wave-like features with 15 to $20^{\circ}$ slopes, situated mainly along the western half of the flank (Figure $4 \mathrm{a}$ ii). The wave features reach a depth of $\sim 430 \mathrm{~m}$ and appear as 'steps' in the seismic profile (Figure 5 S4). The steps observed in the seismic profiles could be interpreted as shoreline terraces; however, their inclination and morphology in the bathymetric map are not clearly linked to shoreline erosion. Phreatomagmatic cones typically release pyroclastic sediments, which in turn can form compression ridges as the sediment moves down slope (Clague, 2009). Therefore, these features could be explained by the stabilization of these pyroclastic deposits, reminiscent of that found along the much deeper and larger slopes of the Hawaiian Ridge (Moore et al. 1989). An alternative theory is that the wave features are formed from turbidity currents produced when volcanoclastic products of the phreatomagmatic eruption entered the lake. This is comparable with the sediment-waves observed downslope of delta fronts in lakes, formed from turbid rivers entering the lake (e.g., Urgeles et al., 2011).

A 20 to $40^{\circ}$ steep sloped wall delimits the northern end of Lake Kivu's Main Basin, and abuts the phreatomagmatic cone of Mount Goma ('D' on Figure 4a ii). This wall corresponds to a superposition of lava from Nyiragongo, whose lava flows frequently extend into Lake Kivu including flows from the 2002 eruption (Figure 3). Subaquatic penetration of lava flows along steeper slopes is expected to break up into debris flows, which cascade down the slopes without extending the land, or collapse the sediment-laden slopes (Morgan et al., 2003; Sansone and Smith, 2006; Mitchell et al., 2008). It is plausible that the lava wall above $250 \mathrm{~m}$ depth was created by lava pouring into the lake from nearby volcanic eruptions during the period of lake-level 
rise, and eventually formed the dam blocking the flow to the north. From a depth of 250 to $315 \mathrm{~m}$, the lake-bottom slope becomes more gentle and irregular and likely consists of the superposition of debris-flow deposits from the lava wall ' $D$ ' and lava flows from the eruption of subaquatic volcanic features in the area (e.g. 'B' and 'C', Figure 4a ii).

At the foot of Mount Goma a dendritic shaped relief occurs between 395 and $425 \mathrm{~m}$ contour ('B' on Figure 4a ii). The fractal outlines of this relief imply its formation as an underwater lava flow, similar to some of the lava flows observed offshore of Pico Island, Azores (Mitchell et al., 2008). Reduced driving-stress is imminent upon lava flowing into water, due to increased buoyancy and cooling-induced viscosity. Furthermore, viscosity, local topography, and flow thickness determine whether the lava will penetrate deeper into the lake or form a delta (Mitchell et al., 2008). There is no association of the relief observed in Figure 4a ii with a lava-delta upslope, suggesting that the flow originated at its location. With respect to the low gradient of the lake bottom directly upslope of the lava, it is also possible that the effusion of lava into the lake occurred when the lake-level was at the $\sim 390$ m contour. However, the seismic profile of the lava flow in Figure 5 S4 and additional seismic profiles that directly cross-cut the lava flow (seismic profiles not shown), indicate a lack of sediment cover. This could suggest a relatively recent age of the flow, or is potentially related to poor seismic penetration due to the hummocky surface of the flow.

Isolated volcanic cones are observed in Figure 4a ii and are aligned NESW with two tuff rings observed in the southeast corner of Frame i. These features probably materialized along a major fault lineament that extends the lake basin from its northern limit to the Idjwi Horst in the south. The cone located $\sim 1 \mathrm{~km}$ south of the shoreline ('C' on Figure $4 \mathrm{a}$ ii) appears constructional, and is reminiscent of subaquatic volcanic cones observed in the ocean that are formed under the confining pressure of a water column (e.g., Clague et al., 2000). However, the 'eroded cones' located $\sim 2 \mathrm{~km}$ to the SW (including 'E' on Figure 4a ii) appear to have a deteriorated topography, which could indicate their subaerial formation.

\subsubsection{Frame iii}

The Main Basin of Lake Kivu is separated from the basin viewed in Figure 4 a iii by a $\sim 500 \mathrm{~m}$ wide, submerged channel. This channel is delimited in the west by the Precambrian rock relief of the Mbuzi Peninsula, which extends into the lake to a depth of 125 to $140 \mathrm{~m}$. The basin has the same 
maximum depth as Kabuno Bay, $\sim 140 \mathrm{~m}$, that is located directly to the northwest (Figure 1) and separated from the Main Basin by a saddle at $12 \mathrm{~m}$ depth. Furthermore, the basin in Frame iii is filled to a depth outlined by the $126 \mathrm{~m}$ contour with warm, salty, and $\mathrm{Fe}^{2+}$-rich water, which is identical to that below the main density gradient in Kabuno Bay. This suggests that the two basins have a hydrogeologic connection, or are fed by the same groundwater source (Ross et al. 2014). A N26 ${ }^{\circ} \mathrm{E}$ oriented depression is located in the northern part of the frame, and is bordered by a $\sim 1 \mathrm{~km}$ NNE-SSW escarpment (' $\mathrm{F}$ ' on Figure 4a iii). The origin of this feature is not known, however, it could be where $\mathrm{Fe}^{2+}$-rich groundwater is discharging into the basin. Distinct depression features have commonly been observed as areas of focused groundwater flow in other lakes and in the ocean (Whiticar, 2002: Bussmann, 2011).

A pronounced hummocky relief dominates this basin, such as that outlined to the east of the depression feature. This relief is probably linked to lava flows from the Nyamulagira volcano. Lava flows from the 1912 eruption of Nyamulagira are responsible for creating the narrow channel and saddle that separates the Main Basin from Kabuno Bay (Pouclet, 1976).

The southwest part of the bathymetry in Frame iii reveals a N33 ${ }^{\circ} \mathrm{E}$ oriented trench calculated from the slope map, which is characterised in its southwestern end by an escarpment oriented towards the SE ('trench' on Figure 4a iii). This feature is interpreted to be an open fracture or fault with an orientation similar to fault strikes encountered in this part of the rift (e.g., Ebinger, 1989; Yamba and Boven, 1998; Corti et al., 2007), and could also be a conduit for groundwater discharge.

\subsection{Region 2}

The Sebeya River meanders through Gisenyi, Rwanda, and is the largest river feeding into Lake Kivu and discharges at its northeastern corner to form a delta ('G' on Figure 4b). The catchment of the basin consists of volcanic and schist terrain, from where rainfall events can induce highly turbid, dense, hyperpycnal flows (Muvundja et al., 2009). At the front of the river mouth, a delta fan and subaquatic channels are observed in the bathymetry in Region 2 , Figure 4b. A step in the delta slope occurs at the $250 \mathrm{~m}$ depth, which likely represents a former shoreline suggested by the pronounced 'submerged channel'. This step could also represent a scar from a collapse of the delta front. However, an associated avalanche deposit is not clearly detectable downslope. 
South of the river, along the eastern shoreline, numerous submerged paleo-valleys sculpted in the Precambrian basement occur. A seismic profile reveals several mass-flow deposits at a depth $\sim 450 \mathrm{~m}$, which are identified by their semi-circular lobe structures and transparent seismic facies that pinches out downslope (Figure 6 S5). The shallowest deposit is located $\sim 4$ m below the modern lake floor and outlined in Figure 6 S5. Mass flows are potentially triggered by ground shaking during seismic activity, which are common in the Kivu Basin (e.g., d'Oreye et al., 2011).

\subsection{Region 3}

The escarpment extending from the Idjwi Island horst structure is observed at the southern limit of Region 3, Figure 4c at a depth of $\sim 460$ $\mathrm{m}$. Lake Kivu sediments are thickest in the vicinity of the horst along the eastern basin, which probably represents the oldest part of the lake (Wood, 2014). At the northern end of the escarpment, a seismic profile reveals an insequence normal fault with a downfaulted eastern part that occurs $\sim 100 \mathrm{~m}$ east of the escarpment (Figure 6 S6). Additional normal faults are observed in the seismic profiles along a NE-SW alignment, which likely propagates to the northern extent of the lake east of the phreatomagmatic cone of Mount Goma. This is coherent with the lineament of subaquatic volcanic features observed in Figure 4b ii that extends northwards to the western limit of Mount Goma. It is possible that these faults are the high-velocity conduits from where cold groundwater discharges into the lake (Figure 3). Cold and dilute groundwater discharge, in addition to hydrothermal discharge, is necessary to maintain the temperature and salinity gradients observed in the deepwater of Lake Kivu (Schmid et al., 2012; Ross et al., 2012).

\section{Lake-level and event reconstruction}

Recent seismic surveys in the eastern part of the Main Basin of Lake Kivu (Wood, 2014), suggest that the lake could be as old as the Miocene. However, the oldest date obtained from the sediment record up to now is $\sim 13.5$ ka (Hecky and Degens, 1973). This date was acquired 40 years ago by radiocarbon analysis of bulk organic matter, which was collected from the bottom of an $8 \mathrm{~m}$ core taken at a depth of $\sim 425 \mathrm{~m}$ in the Main Basin (Degens et al., 1973). An additional core collected by the same team revealed coarse rounded pebbles at a depth of $\sim 315 \mathrm{~m}$, which implied a lake-level lowstand with an inferred age of 12-14 ka. These results were consistent with seismic 
surveys conducted by Wong and von Herzen (1974), which revealed a thin veneer of sediment covering depths of less than $300 \mathrm{~m}$ in the southern part of the lake. The authors concluded that prior to the lake-level rise and subsequent draining via the Ruzizi River $\sim 10$ ka the lake-level lowstand was $\sim 300 \mathrm{~m}$, and that the lake was hydrologically closed so that the lake level fluctuated depending on rates of precipitation and evaporation.

The high-resolution bathymetric survey and seismic profiles presented here suggest the presence of at least four paleoshorelines at 425, 395, 315, and $250 \mathrm{~m}$ depth. A timeline for the transgression of these shorelines and the relative dates of volcanic activity in Lake Kivu is outlined in this section. The timeline is inferred from our data in addition to the published analysis of the cores gathered by this investigation and previous research conducted on Lake Kivu and Lake Tanganyika, which is summarized in Table 1.

\subsection{Paleoshorelines}

The paleoshoreline at $425 \mathrm{~m}$ depth outlines the isolated volcanic features and the northward extension of the Idjwi Island horst, and is the lower limit of the submerged erosional valleys in the east (Figure 2b). From the analysis of the high-resolution bathymetric map, the morphology at depths greater than $425 \mathrm{~m}$ is dominated by enhanced sediment deposition (Figure 2b). This implies an older age of the basin below $425 \mathrm{~m}$ depth where prolonged sediment deposition appears to even out the morphology. Furthermore, the seismic penetration into the sediment is largest at depths greater than 425 m implying a thicker sedimentary basin below this depth (e.g. Figure 6 S6). The eroded river valleys in the east and the volcanic platform in the west are clearly outlined by the $395 \mathrm{~m}$ contour. The morphology appears relatively smooth between the 425 and $395 \mathrm{~m}$ contour when compared to shallower water depths, which suggests a more substantial sediment cover below the $395 \mathrm{~m}$ depth. From this assessment, we infer that the $425 \mathrm{~m}$ paleoshoreline represents the lake level prior to the volcanism in this region initiated at 100 ka Rogers et al. (1998). At this time volcanism in the western VVP was active and consequently began to form the dam linked to the lake-level rise. The lake level prior to 100 ka could have fluctuated greatly. However, lake-level rise would have been limited by the height of the lava dam in the north. Following the late Pleistocene and before the active initiation of the Nyiragongo volcanism at $\sim 15 \mathrm{ka}$, the lake level is assumed to have risen to the $395 \mathrm{~m}$ paleoshoreline. A lake-level rise from the 425 to $395 \mathrm{~m}$ depth is documented by shoreline terraces observed in Figure 6 S1 and S2. 
We postulate that the $425 \mathrm{~m}$ paleoshoreline represents the late Pleistocene lowstand that was suggested to have been at $300 \mathrm{~m}$ by Hecky and Degens (1973). As a consequence of the active volcanism $\sim 15 \mathrm{ka}$, the lake-level rise is expected to have become more rapid with the increasing dam elevation in the north. The dam formation in conjunction with the onset of the Holocene, during which wetter climates prevailed, rapidly led to the eventual overflow via the Ruzizi River $\sim 10$ ka. The inundation of the active volcanoes and the onset of the deep lake marked the beginning of the hydrothermal activity and subsequent thermohaline stratification in Lake Kivu (Table 1).

\subsection{Volcanism}

Two additional paleoshorelines are postulated at the 315 and $250 \mathrm{~m}$ contours. These depths outline the base of tuff rings and maars in the western part of the basin. The sedimentation recorded within 4 tuff rings that are formed from shallow-water eruptions implies that these features culminated during the period of lake-level rise $\sim 9-14$ ka (Figure $4 \mathrm{~b}$ ). The $250 \mathrm{~m}$ contour also outlines the steep lava wall delimiting the Main Basin to the north, further signifying volcanic activity in connection with a rapid lake-level rise. Additional evidence of volcanic activity at $\sim 10$ ka was observed in a $3.2 \mathrm{~m}$ long core provided by Hecky and Degens (1973), which terminated in a nearly $2 \mathrm{~m}$ thick ash layer. The core was taken in proximity to the volcanic platform, at a point southeast of the isolated tuff cone observed in Figure 4a i. This ash layer likely coincides with the formation of the maars and tuff rings at the 315 or $250 \mathrm{~m}$ depth, where shallow-water eruptions typically disperse considerable quantities of ash (Zimanowski and Büttner, 2003). Elemental analysis conducted by Degens and Kulbicki (1973) and Haberyan and Hecky (1987) suggested that intense hydrothermal activity inside Lake Kivu was initiated abruptly at $\sim 5 \mathrm{ka}$ (or at $138 \mathrm{~cm}$ core depth). Furthermore, Felton et al. (2007) observed an increase in all elements in the sediment of Lake Tanganyika at $\sim 4 \mathrm{ka} \mathrm{BP}$ to the top of the core. Although they attributed this rise in elements to renewed overflow at the Ruzizi outlet (Table 1), it could be correlated with increased hydrothermal activity in Lake Kivu. Similar characteristics of increased volcanic activity were observed again by Haberyan and Hecky (1987) at $\sim 1 \mathrm{ka}(32 \mathrm{~cm}$ core depth), and constrained to $\sim 0.8 \mathrm{ka}$ by the present investigation (Ross et al., 2013). Lower intensity volcanism, or hydrothermal pulses, were recorded in the sediment at $\sim 0.6$ and 0.4 ka and could represent the most recent subaquatic volcanic activity determined in Lake Kivu (Ross et al., 2013). 
Observations of subaquatic volcanic activity recorded in the sediment of Lake Kivu imply that the subaquatic volcanic features observed in the highresolution bathymetry, including the volcanic dome in Figure 4a i ('A'), and the subaquatic volcanic cone and the apparent lava flow in Figure 4a ii ('C' and 'B'), were formed sometime after the onset of the Holocene but were not significantly active prior to $\sim 4-5$ ka. Furthermore, we can postulate from the morphological analysis and seismic profiles that the phreatomagmatic cone Mount Goma has been active following the lake-level rise at the beginning of the Holocene, but is likely much older than the lava flow that crosscuts its pyroclastic sediment waves ('B' on Figure 4a). Hydrothermal activity is a typical indicator of active subaquatic volcanism (Ohsawa et al., 2002; Morgan et al., 2003; Clague, 2009) and is concentrated in Lake Kivu at the volcanic platform in the west in Figure 3; within the basin in Figure 4a iii, and at the dome feature observed in Figure 4a i. Hydrothermal activity following the lake-level rise in the early Holocene, and still observed in the Main Basin today, maintains the current state of meromixis in Lake Kivu (Schmid et al. 2005). Not surprisingly, hydrothermal activity appears to be linked to geological activity in Lake Kivu, and intense hydrothermal events are correlated to volcanism and lake-mixing events (Haberyan and Hecky, 1987; Ross et al., 2013, 2012).

\section{Conclusion on threat of a lake overturn}

It is generally presumed that volcanic and seismic activity occurring within Lake Kivu would lead to an overturn of the lake and subsequent expulsion of its dissolved gases. The marked volcanic events at $\sim 5$ and 0.8 ka (Table 1) are linked to a lake-mixing event such as a limnic eruption. In particular, drastic changes in the flora and fauna were recorded immediately following the event at $\sim 5$ ka (Haberyan and Hecky, 1987) that indicated significant geochemical changes in the water column. Furthermore, a distinct subaquatic-tephra layer and a change in deepwater carbonate saturation are recored in the sediments at $\sim 0.8$ ka (Ross et al., 2013). An indication of toxic deepwater having been mixed into surface water is inferred from the genetically much younger cichlid fish in Lake Kivu than those in lake Edward and Victoria (Bezault et al., 2011), despite the implied Miocene age of Lake Kivu. However, there is still no conclusive evidence to link geologic features observed on the lake floor to an occurrence of a lake overturn triggered by volcanism or rift tectonics. Preliminary estimates of the effect of a plume 
formed by a subaquatic magmatic intrusion suggested that such an event would not be sufficient to trigger a catastrophic gas release at the present stratification and gas concentrations (Schmid et al., 2003), but a thorough hazard assessment still needs to be conducted. The high-resolution bathymetric mapping of the Main Basin of Lake Kivu reveals an unprecedented look at geologic features in this area, including volcanic features that might have been active at least within the last $\sim 1$ kyrs. The young age of these features in addition to the 2002 volcano-tectonic eruption of Nyiragongo, and its probable dyke intrusion beneath the lake, suggest that a sublacustrine eruption in Lake Kivu is a possible threat. A brief summary of the volcanism associated with the dynamics of Lake Kivu is as follows:

i late Pleistocene - active volcanism in the western VVP

ii $10 \mathrm{ka}$ - damming of Lake Kivu by active volcanism, leading to overflow of the lake at the Ruzizi River to Lake Tanganyika

iii $5 \mathrm{ka}$ - intense deep hydrothermal activity linked to volcanism in Lake Kivu, and possibly a lake overturn

iv 1-0.8 ka - intense hydrothermal activity linked to volcanism in Lake Kivu, and breakdown of thermohaline stratification

v 0.6-0.4 ka - moderate hydrothermal activity linked to perturbation of thermohaline stratification

vi 10 years ago - flank eruption of Nyiragongo linked to a possible dyke that propagates beneath Lake Kivu

Earthquakes have also been documented within Lake Kivu, where their occurrence could lead to mass-movements in the sublacustrine basin, including that observed in Figure 6 S5. Such mass-movements, if substantially large, could cause tsunami waves and seiches (e.g., Schnellmann et al., 2002) that eventually could trigger the expulsion of gases from the lake. Furthermore, the increasing concentrations of the dissolved gases and the possibility of their inherent combined partial pressures overcoming the hydrostatic pressures of the lake is a commonly referenced threat (e.g., Tietze, 1991, 1992; Schmid et al., 2003). The present increase of the gases in the water column is linked to an increase in the groundwater discharge into the lake (Schmid et al. 2005, 2012). Since hydrothermal groundwater discharge has a causative effect 
on the thermohaline stratification, and is a product of volcanism in the lake, then monitoring changes in hydrothermal activity could yield early warning signs of a gas outburst. Hydrothermal activity concentrated along volcanic features in the sublacustrine environment can be monitored with CTD profiling, or moored sensors (Baker et al., 2012). Additionally, the bathymetric map presented here can be used to monitor developments in the Kivu sublacustrine basin, where changes to volcanic features over time can be observed by modern acoustic techniques (e.g., Caress et al., 2012; Chadwick Jr et al., 2012; Watts et al., 2012). In conclusion, the new high-resolution geomorphologic dataset will greatly aid in the assessment of a potentially catastrophic eruption. Additional studies on the subaquatic volcanoes observed in this map should focus on the possible activity of the young geomorphological features, including features 'A' and 'B' in Figure 4a.

\section{Acknowledgement}

This project was financially supported by the Swiss National Science Foundation (SNSF) and the Swiss Agency for Development and Cooperation under grant IZ70Z0-123923 (Lake Kivu: Learning from the past for managing its future). Part of this work was performed in the frame of the NYALHA project funded by the National Research Fund of Luxembourg (AFR PhD Grant n3221321) and the GeoRisCA project funded by the Belgian Science Policy. Fieldwork was conducted with research permission from the Ministry of Infrastructure on the Rwanda side of the lake, and arrangements were made with the Congolese Marine on the DRC side of the lake. We would like to thank F. Muvundja, N. Pasche, K. Karume, C. Balagizi, A. Gafasi, and the crew of the R.V. Gloria for their support during the sampling campaign. We would also like to thank the team from RCMG, W. Versteeg and K. De Rycker, for acquistion of the bathymetric data. We greatly appreciate the support from A. Wüest, M. Hilbe, M. Van Daele, J. Greinert, D. Clague, and W. W. Chadwick for processing and interpretive analysis of the bathymetric data. Lastly, we would like to kindly acknowledge the anonymous reviewers for their constructive ideas that helped to finalize this manuscript.

Baker, E. T., Chadwick, W. W., Cowen, J. P., Dziak, R. P., Rubin, K. H., Fornari, D. J., 2012. Hydrothermal discharge during submarine eruptions: The importance of detection, response, and new technology. Oceanography 25 (1), 128-141. 
Bezault, E., Mwaiko, S., Seehausen, O., 2011. Population genomic tests of models of adaptive radiation in Lake Victoria region cichlid fish. Evolution 65 (12), 3381-3397.

Bhattarai, S., Ross, K. A., Schmid, M., Anselmetti, F. S., Bürgmann, H., 2012. Local conditions structure unique Archaeal communities in the anoxic sediments of meromictic Lake Kivu. Microbial Ecology 64 (2), 291310.

Boutakoff, N., 1939. Géologie des territoires situés à l'ouest et au nordouest du fossé tectonique du kivu. Ph.D. thesis, Institut Géologique de l'Université.

Bussmann, I., 2011. Active pockmarks in a large lake (Lake Constance, Germany): Effects on methane distribution and turnover in the sediment. Limnology and Oceanography 56 (1), 379-393.

Capaccioni, B., Vaselli, O., Santo, A., Yalire, M., 2003. Monogenic and polygenic volcanoes in the area between the Nyiragongo summit crater and the Lake Kivu shoreline. Acta Vulcanologica 14 (1/2), 129-136.

Caress, D. W., Clague, D. A., Paduan, J. B., Martin, J. F., Dreyer, B. M., Chadwick Jr, W. W., Denny, A., Kelley, D. S., 2012. Repeat bathymetric surveys at 1-metre resolution of lava flows erupted at Axial Seamount in April 2011. Nature Geoscience 5 (7), 483-488.

Chadwick Jr, W. W., Nooner, S. L., Butterfield, D. A., Lilley, M. D., 2012. Seafloor deformation and forecasts of the April 2011 eruption at Axial Seamount. Nature Geoscience 5 (7), 474-477.

Chen, C.-T. A., Millero, F. J., 1986. Precise thermodynamic properties for natural waters covering only the limnological range. Limnology and Oceanography 31 (3), 657-662.

Clague, D. A., 2009. Accumulation rates of volcaniclastic deposits on Loihi Seamount, Hawaii. Bulletin of Volcanology 71 (6), 705-710.

Clague, D. A., Moore, J. G., Reynolds, J. R., 2000. Formation of submarine flat-topped volcanic cones in Hawai'i. Bulletin of Volcanology 62 (3), 214233. 
Corti, G., van Wijk, J., Cloetingh, S., Morley, C., 2007. Tectonic inheritance and continental rift architecture: Numerical and analogue models of the East African Rift system. Tectonics 26 (6), TC6006.

Degens, E. T., Kulbicki, G., 1973. Hydrothermal origin of metals in some East African rift lakes. Mineralium Deposita 8 (4), 388-404.

Degens, E. T., von Herzen, R. P., Wong, H.-K., Deuser, W. G., Jannasch, H. W., 1973. Lake Kivu: structure, chemistry and biology of an East African rift lake. Geologische Rundschau 62 (1), 245-277.

Denaeyer, M., 1975. Le glacis des volcans actifs au Nord du lac Kivu (République du Zaïre). Vol. 31-35. Éditions du Muséum National d'Histoire Naturelle.

d'Oreye, N., González, P. J., Shuler, A., Oth, A., Bagalwa, L., Ekström, G., Kavotha, D., Kervyn, F., Lucas, C., Lukaya, F., et al., 2011. Source parameters of the 2008 Bukavu-Cyangugu earthquake estimated from InSAR and teleseismic data. Geophysical Journal International 184 (2), 934-948.

Ebinger, C., 1989. Tectonic development of the western branch of the East African rift system. Geological Society of America Bulletin 101 (7), 885903.

Felton, A. A., Russell, J. M., Cohen, A. S., Baker, M. E., Chesley, J. T., Lezzar, K. E., McGlue, M. M., Pigati, J. S., Quade, J., Curt Stager, J., Jacques, T., 2007. Paleolimnological evidence for the onset and termination of glacial aridity from Lake Tanganyika, Tropical East Africa. Palaeogeography, Palaeoclimatology, Palaeoecology 252 (3), 405-423.

Gilli, A., Anselmetti, F., Ariztegui, D., Beres, M., McKenzie, J., Markgraf, V., 2005. Seismic stratigraphy, buried beach ridges and contourite drifts: the Late Quaternary history of the closed Lago Cardiel basin, Argentina (49 S). Sedimentology 52 (1), 1-23.

Haberyan, K. A., Hecky, R. E., 1987. The late Pleistocene and Holocene stratigraphy and paleolimnology of Lakes Kivu and Tanganyika. Palaeogeography, Palaeoclimatology, Palaeoecology 61, 169-197. 
Halbwachs, M., Sabroux, J.-C., Grangeon, J., Kayser, G., Tochon-Danguy, J.-C., Felix, A., et al., 2004. Degassing the killer Lakes Nyos and Monoun, Cameroon. Eos, Transactions American Geophysical Union 85 (30), 281.

Hamilton, C., Thordarson, T., Fagents, S., 2010. Explosive lava-water interactions I: architecture and emplacement chronology of volcanic rootless cone groups in the 1783-1784 Laki lava flow, Iceland. Bulletin of Volcanology $72(4), 449-467$.

Hecky, R. E., Degens, E. T., 1973. Late Pleistocene-Holocene chemical stratigraphy and paleolimnology of the Rift Valley lakes of Central Africa. WHOI technical report, Woods Hole Oceanographic Institution, Woods Hole, Mass.

Herrincks, P., 1959. Séismicité du congo belge. Académie Royale des Sciences Coloniales, Classe des Sciences Naturelles Médicales, Mémoire in $8^{\circ}$ nouv. $9(5), 1-55$.

Jenness, J., 2012. DEM Surface Tools. Jenness Enterprises.

Kavotha, S., Mavonga, T., Durieux, J., Mukambilwa, K., 2003. Towards a more detailed seismic picture of the January 17th, 2002 Nyiragongo eruption. Acta Vulcanologica 14/15 (1/2), 15-28.

Kling, G. W., Clark, M. A., Wagner, G. N., Compton, H. R., Humphrey, A. M., Devine, J. D., Evans, W. C., Lockwood, J. P., Tuttle, M. L., Koenigsberg, E. J., 1987. The 1986 Lake Nyos gas disaster in Cameroon, West Africa. Science 236 (4798), 169-175.

Komorowski, J., 2003. The January 2002 flank eruption of Nyiragongo volcano (Democratic Republic of Congo): Chronology, evidence for a tectonic rift trigger, and impact of lava flows on the city of Goma. Acta vulcanologica $14 / 15(1 / 2), 27-62$.

Lahmeyer, O., 1998. Bathymetric survey of Lake Kivu. Final report. Tech. rep., Republic of Rwanda, Ministry of Public Work, Directory of Energy and Hydrocarbons, Kigali.

Lorenz, V., 1986. On the growth of maars and diatremes and its relevance to the formation of tuff rings. Bulletin of Volcanology 48 (5), 265-274. 
Lorke, A., Tietze, K., Halbwachs, M., Wüest, A., 2004. Response of Lake Kivu stratification to lava inflow and climate warming. Limnology and Oceanography 49 (3), 778-783.

Lyons, R. P., Scholz, C. A., Buoniconti, M. R., Martin, M. R., 2011. Late quaternary stratigraphic analysis of the lake malawi rift, east africa: an integration of drill-core and seismic-reflection data. Palaeogeography, Palaeoclimatology, Palaeoecology 303 (1), 20-37.

Mavonga, T., Kavotha, S. K., Lukaya, N., Etoy, O., Durieux, J., 2006. Seismic activity prior to the May 8, 2004 eruption of volcano Nyamuragira, Western Rift Valley of Africa. Journal of Volcanology and Geothermal Research 158 (3), 355-360.

Mavonga, T., Zana, N., Durrheim, R., 2010. Studies of crustal structure, seismic precursors to volcanic eruptions and earthquake hazard in the eastern provinces of the Democratic Republic of Congo. Journal of African Earth Sciences 58 (4), 623-633.

McGlue, M. M., Scholz, C. A., Karp, T., Ongodia, B., Lezzar, K. E., 2006. Facies architecture of flexural margin lowstand delta deposits in Lake Edward, East African rift: constraints from seismic reflection imaging. Journal of Sedimentary Research 76 (6), 942-958.

Mitchell, N. C., Beier, C., Rosin, P. L., Quartau, R., Tempera, F., 2008. Lava penetrating water: submarine lava flows around the coasts of Pico Island, Azores. Geochemistry Geophysics Geosystems 9 (3), Q03024.

Moore, J., Clague, D., Holcomb, R., Lipman, P., Normark, W., Torresan, M., 1989. Prodigious submarine landslides on the Hawaiian Ridge. Journal of Geophysical Research 94 (B12), 17465-17484.

Morgan, L., Shanks, W., Lovalvo, D., Johnson, S., Stephenson, W., Pierce, K., Harlan, S., Finn, C., Lee, G., Webring, M., et al., 2003. Exploration and discovery in Yellowstone Lake: results from high-resolution sonar imaging, seismic reflection profiling, and submersible studies. Journal of Volcanology and Geothermal Research 122 (3), 221-242.

Muvundja, F. A., Pasche, N., Bugenyi, F. W., Isumbisho, M., Müller, B., Namugize, J.-N., Rinta, P., Schmid, M., Stierli, R., Wüest, A., 2009. Bal- 
ancing nutrient inputs to Lake Kivu. Journal of Great Lakes Research 35 (3), 406-418.

Ohsawa, S., Kazahaya, K., Yasuhara, M., Kono, T., Kitaoka, K., Yusa, Y., Yamaguchi, K., 2002. Escape of volcanic gas into shallow groundwater systems at Unzen Volcano (Japan): evidence from chemical and stable carbon isotope compositions of dissolved inorganic carbon. Limnology 3 (3), 169173.

Olson, E. A., Broecker, W. S., 1959. Lamont natural radiocarbon measurements, [Part] 5. American Journal of Science 257 (1), 1-28.

Pasche, N., Schmid, M., Vazquez, F., Schubert, C. J., Wüest, A., Kessler, J. D., Pack, M. A., Reeburgh, W. S., Bürgmann, H., 2011. Methane sources and sinks in Lake Kivu. Journal of Geophysical Research 116 (G3), G03006.

Peeters, L., 1957. Contribution à l'étude de la genèse du lac Kivu. Bulletin Société Belge Etudes Géographiques 26, 155-168.

Pouclet, A., 1976. Volcanologie du rift de l'Afrique Centrale, Le Nyamuragira dans les Virunga, essai de magmatologie du rift. Ph.D. thesis, University of Paris-Sud (Orsay).

Rogers, N., James, D., Kelley, S., De Mulder, M., 1998. The generation of potassic lavas from the eastern Virunga province, Rwanda. Journal of Petrology 39 (6), 1223-1247.

Ross, K. A., Gafasi, A., Gashugi, E., Wüest, A., Schmid, M., 2014. Characterisation of the subaquatic groundwater discharge into the main basin of lake kivu; east africa. Submitted to Hydrology and Earth System Sciences.

Ross, K. A., Schmid, M., De Batist, M., Anselmetti, F., Wüest, A., Jul. 2012. Subaquatic groundwater discharge sustains the stratification in Lake Kivu preventing the eruption of gas from the deepwater, ASLO, Aquatic Sciences Meeting, Lake Biwa.

Ross, K. A., Schmid, M., Ogorka, S., Muvundja, F. A., Anselmetti, F. S., September 2013. The history of subaquatic volcanism recorded in the sediments of Lake Kivu, East Africa. Accepted for publication in Journal of Paleolimnology. 
Sansone, F. J., Smith, J. R., 2006. Rapid mass wasting following nearshore submarine volcanism on Kilauea volcano, Hawaii. Journal of Volcanology and Geothermal Research 151 (1), 133-139.

Schmid, M., Halbwachs, M., Wehrli, B., Wüest, A., 2005. Weak mixing in Lake Kivu: New insights indicate increasing risk of uncontrolled gas eruption. Geochemistry Geophysics Geosystems 6 (7), Q07009.

Schmid, M., Ross, K., Wüest, A., 2012. Comment on "An additional challenge of Lake Kivu in Central Africa Upward Movement of the Chemoclines" by Finn Hirslund. Journal of Limnology 71 (2), e35.

Schmid, M., Tietze, K., Halbwachs, M., Lorke, A., McGinnis, D., Wüest, A., 2003. How hazardous is the gas accumulation in Lake Kivu? Arguments for a risk assessment in light of the Nyiragongo Volcano eruption of 2002. Acta vulcanologica 14/15 (1/2), 115-122.

Schmid, M., Wüest, A., 2012. Stratification, mixing and transport processes in Lake Kivu. In: Descy, J.-P., Darchambeau, F., Schmid, M. (Eds.), Lake Kivu. Springer, Ch. 2, pp. 13-29.

Schnellmann, M., Anselmetti, F., Giardini, D., McKenzie, J., Ward, S., 2002. Prehistoric earthquake history revealed by lacustrine slump deposits. Geology 30 (12), 1131-1134.

Smets, B., Tedesco, D., Kervyn, F., Kies, A., Vaselli, O., Yalire, M. M., 2010a. Dry gas vents ("mazuku") in Goma region (North-Kivu, Democratic Republic of Congo): Formation and risk assessment. Journal of African Earth Sciences 58 (5), 787-798.

Smets, B., Wauthier, C., d'Oreye, N., 2010b. A new map of the lava flow field of Nyamulagira (DR Congo) from satellite imagery. Journal of African Earth Sciences 58 (5), 778-786.

Stoffers, P., Hecky, R. E., 1978. Late Pleistocene-Holocene evolution of the Kivu-Tanganyika Basin. Modern and Ancient Lake Sediments 2, 43-55.

Tassi, F., Vaselli, O., Tedesco, D., Montegrossi, G., Darrah, T., Cuoco, E., Mapendano, M., Poreda, R., Huertas, A. D., 2009. Water and gas chemistry at Lake Kivu (DRC): Geochemical evidence of vertical and horizontal heterogeneities in a multibasin structure. Geochemistry Geophysics Geosystems 10 (2), Q02005. 
Tazieff, H., 1977. An exceptional eruption: Mt. Niragongo, January 10th, 1977. Bulletin of Volcanology 40 (3), 189-200.

Tedesco, D., Tassi, F., Vaselli, O., Poreda, R., Darrah, T., Cuoco, E., Yalire, M., 2010. Gas isotopic signatures (He, C, and Ar) in the Lake Kivu region (western branch of the East African rift system): Geodynamic and volcanological implications. Journal of Geophysical Research 115 (B1), B01205.

Tietze, K., 1991. Potential hazard and possible utilization of dissolved gases in stratified lakes, exemplified by lakes Nyos and Kivu. Vol. 24. Verh. Internat. Verein. Limnol.

Tietze, K., 1992. Cyclic gas bursts: are they a usual feature of Lake Nyos and other gas-bearing lakes. Natural Hazards in West and Central Africa, International Monograph Series on Interdisciplinary Earth Science Research and Applications, 97-107.

Tietze, K., Geyh, M., Müller, H., Schröder, L., Stahl, W., Wehner, H., 1980. The genesis of the methane in Lake Kivu (Central Africa). Geologische Rundschau 69 (2), 452-472.

Urgeles, R., Cattaneo, A., Puig, P., Liquete, C., De Mol, B., Amblàs, D., Sultan, N., Trincardi, F., 2011. A review of undulated sediment features on Mediterranean prodeltas: distinguishing sediment transport structures from sediment deformation. Marine Geophysical Research 32 (1), 49-69.

Verhoogen, J., 1948. Les éruptions 1938-1940 du volcan Nyamuragira. Institut des Parcs Nationaux du Congo Belge.

Watts, A., Peirce, C., Grevemeyer, I., Paulatto, M., Stratford, W., Bassett, D., Hunter, J., Kalnins, L., de Ronde, C., 2012. Rapid rates of growth and collapse of Monowai submarine volcano in the Kermadec arc. Nature Geoscience 5 (7), 510-515.

Wauthier, C., Cayol, V., Kervyn, F., d'Oreye, N., 2010. Modeling of InSAR displacements related with the January 2002 eruption of Nyiragongo volcano. In: ECGS Blue Books. 
Wauthier, C., Cayol, V., Kervyn, F., d'Oreye, N., 2012. Magma sources involved in the 2002 Nyiragongo eruption, as inferred from an InSAR analysis. Journal of Geophysical Research 117 (B5), B05411.

Wessel, P., Smith, W. H., 1991. Free software helps map and display data. Eos, Transactions, AGU 72 (441), 445-446.

Whiticar, M. J., 2002. Diagenetic relationships of methanogenesis, nutrients, acoustic turbidity, pockmarks and freshwater seepages in Eckernförde Bay. Marine Geology 182 (1), 29-53.

Wong, H.-K., von Herzen, R. P., 1974. A geophysical study of Lake Kivu, East Africa. Geophysical Journal of the Royal Astronomical Society 37 (3), 371-389.

Wood, D. A., 2014. Structure, paleolimnology and basin history of the east kivu graben, lake kivu, rwanda from offshore seismic reflection data. Master's thesis, Syracuse University.

Yamba, T., Boven, A., 1998. Evolution Pliocène et Quaternaire du remplissage sédimentaire dans le sud du bassin du lac Edouard, branche occidentale du Rift Est-Africain. Journal of African Earth Sciences 26 (3), 423-439.

Zimanowski, B., Büttner, R., 2003. Phreatomagmatic explosions in subaqueous volcanism. Geophysical Monograph Series 140, GM03. 
Table 1: Inferred lake-level changes and hydrothermal activity over the past 14 kyrs

\begin{tabular}{|c|c|c|}
\hline Events & *Date (ka) & lake-level (m) \\
\hline $\begin{array}{l}\text { Nyiragongo and Nyamulagira become active } \\
\text { and dam the outflow to Lake Edward }{ }^{1,2,3,4,5,6}\end{array}$ & $14-10$ & -300 or lower \\
\hline $\begin{array}{l}\text { Initiation of hydrothermal activity and strat- } \\
\text { ification linked to overflow at Ruzizi to Lake } \\
\text { Tanganyika }{ }^{2,4,5,8}\end{array}$ & $10-8$ & present to +100 \\
\hline $\begin{array}{l}\text { Possible brief cessation in overflow and break- } \\
\text { down of stratification in period }{ }^{2,6}\end{array}$ & $8-6$ & present to -100 \\
\hline $\begin{array}{l}\text { Sudden change in lake chemistry attributed to } \\
\text { extreme hydrothermal event - followed by initi- } \\
\text { ation of thermohaline stratification }\end{array}$ & 5 & near present \\
\hline $\begin{array}{l}\text { Extreme hydrothermal event - breakdown of } \\
\text { stratification }{ }^{1,2,3,9}\end{array}$ & $1-0.8$ & near present \\
\hline $\begin{array}{l}\text { Renewed thermohaline stratification, lake } \\
\text { chemistry progressively reaches its current } \\
\text { state }^{1,2,4,9}\end{array}$ & $1-0$ & present \\
\hline
\end{tabular}

* Dates are rounded to the nearest thousand and are based upon radiocarbon analysis of sediment, with the exception of those derived from Ross et al. (2013). A range implies a duration, or more than one date calculated for the same event. 1 Degens et al., 1973

2 Hecky and Degens, 1973

3 Stoffers and Hecky, 1978

4 Degens and Kulbicki, 1973

5 Haberyan and Hecky, 1987

6 Felton et al., 2007

${ }^{7}$ Wong and von Herzen, 1974

8 Olson and Broecker, 1959

${ }^{9}$ Ross et al., 2013 


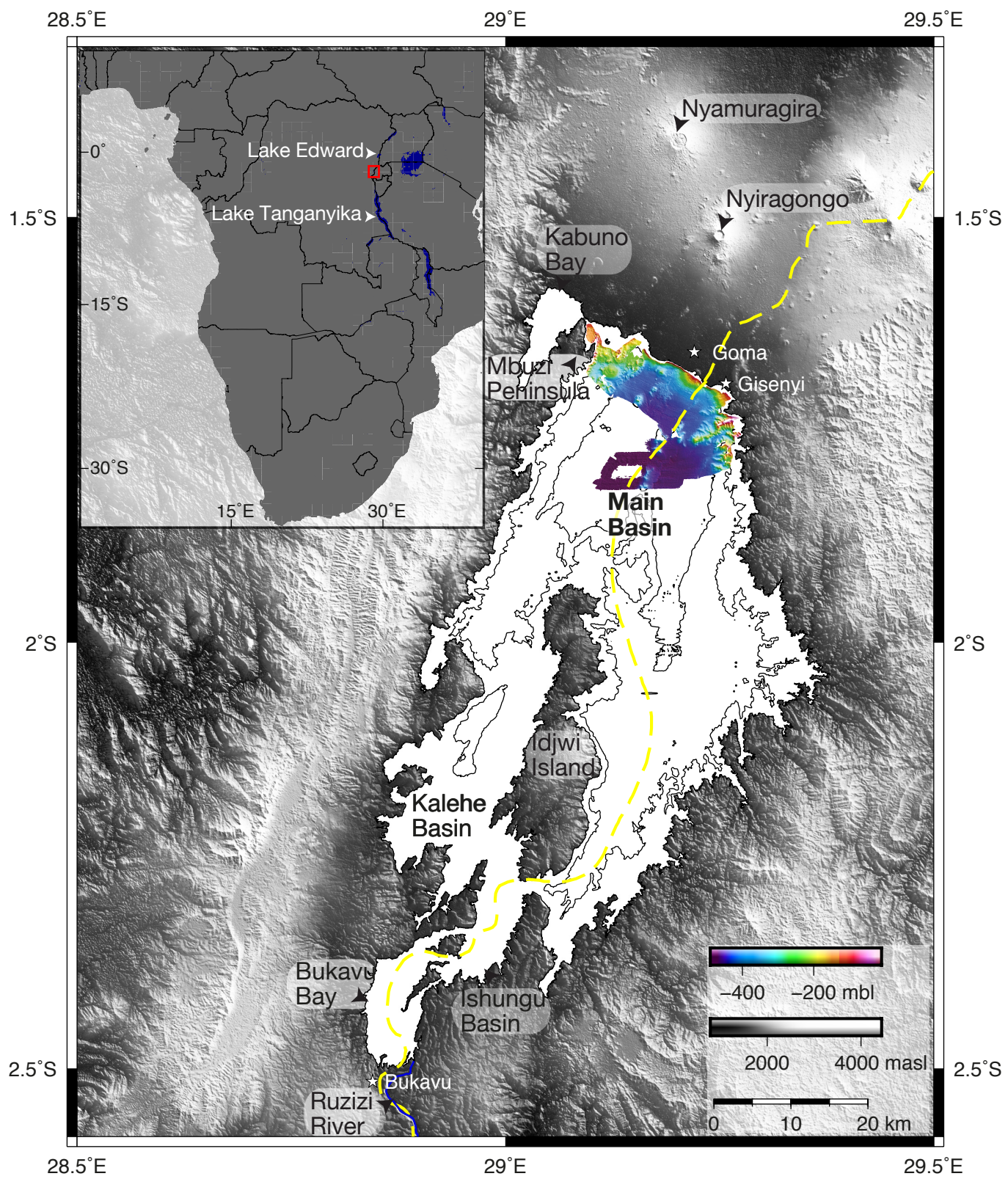

Figure 1: Overview map of Lake Kivu's basin. The inset represents the location of the Kivu Basin within Africa. Main figure: Gray scale, $30 \mathrm{~m}$ ASTER Global DEM (GDEM) data displaying Nyiragongo and Nyamulagira volcanoes north of the lake (ASTER GDEM is a product of METI and NASA). Yellow discontinuous line is the border separating the Democratic Republic of Congo to the west and Republic of Rwanda to the east. Black contour lines represent the 200 and $400 \mathrm{~m}$ depths in the lake. Coloured map overlaying the lake represents the $224 \mathrm{~km}^{2}$ area of high-resolution bathymetry data acq 2 iged within the Main Basin, and used for analysis of observed features. 


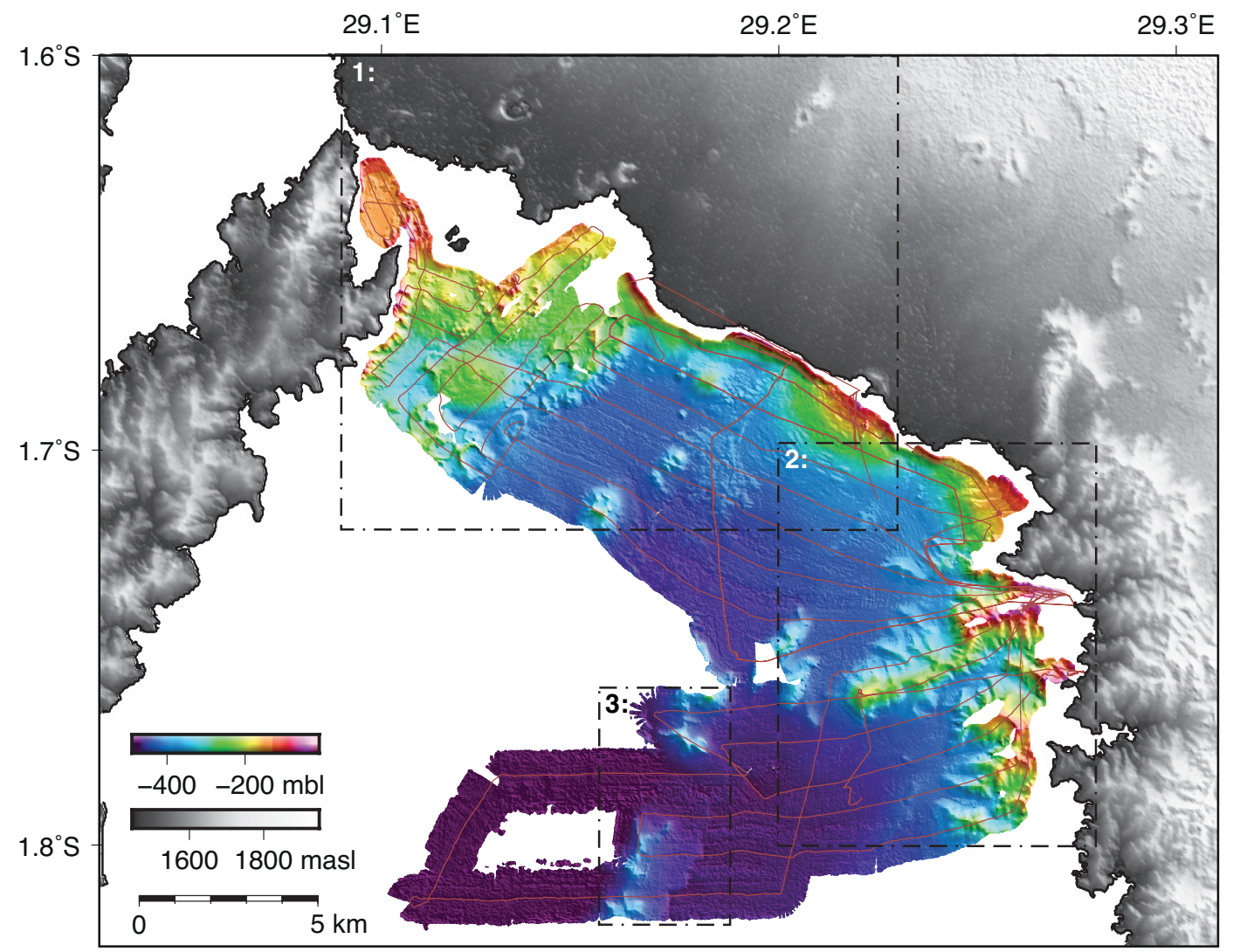

(a) The $10 \mathrm{~m}$ resolution bathymetric map sectioned into 3 regions (1, 2 and 3$)$; used for morphological analysis. Tracklines from the bathymetric survey are delineated in red. 


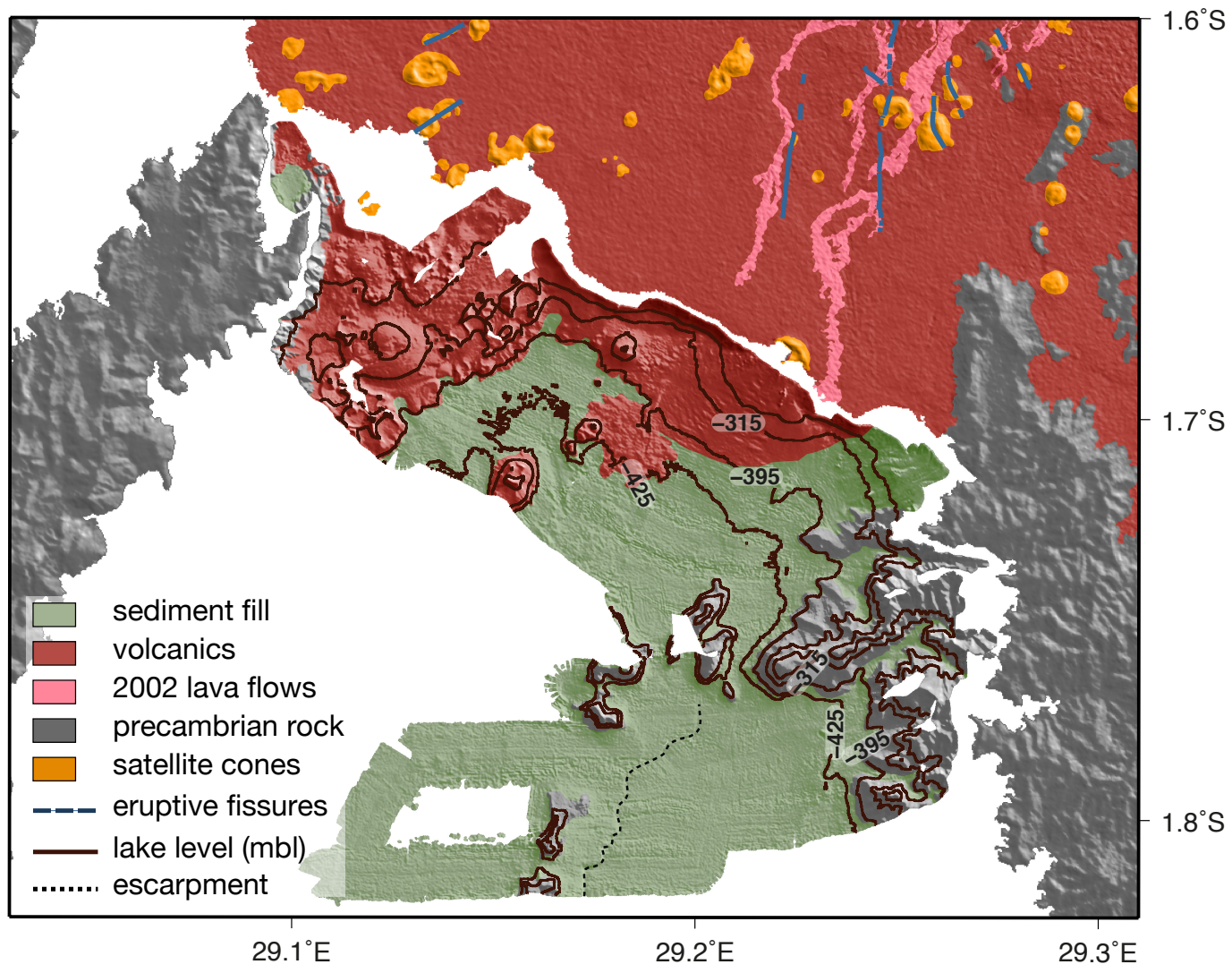

(b) The interpretive map displaying the general morphological features including hummocky volcanic relief, Precambrian rock structures, drowned river valleys, enhanced sediment deposition, and the paleoshorelines represented by depth contours; 425, 395, 315, and $250 \mathrm{~m}$. Satellite cones, eruptive fissures and the lava flows from the 2002 eruption of Nyiragongo are marked on the subaerial terrain. The escarpment of the Idjwi Island horst is outlined on the southeastern part of the map.

Figure 2: High resolution bathymetric map 


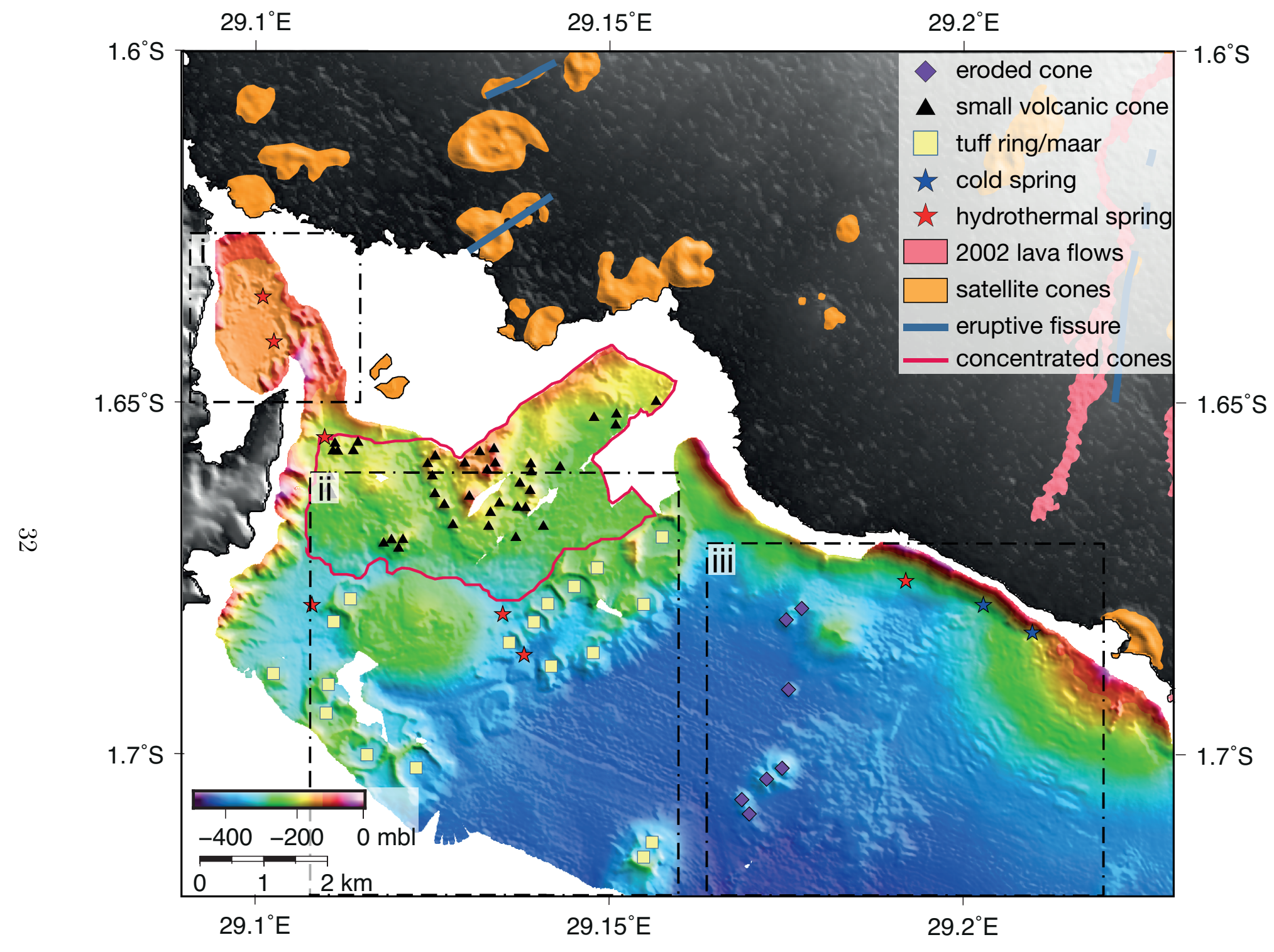

Figure 3: Region 1: Volcanic features including rootless cones (outlined by the polygon 'concentrated cones'), tuff rings and maars, hydrothermal and cold groundwater discharge locations. The subaerial features include the satellite cones (the phreatomagmatic cone 'Mount Goma' is named), eruptive fissures, and the lava flows from the 2002 Nyiragongo eruption. The figure is sectioned into 3 frames (i, ii, and iii) for further morphologic and structural ananlysis. Three subaquatic features observed here are marked on the map in Figure 4a. dome 'A', lava flow 'B', and volcanic cone 'C'. 


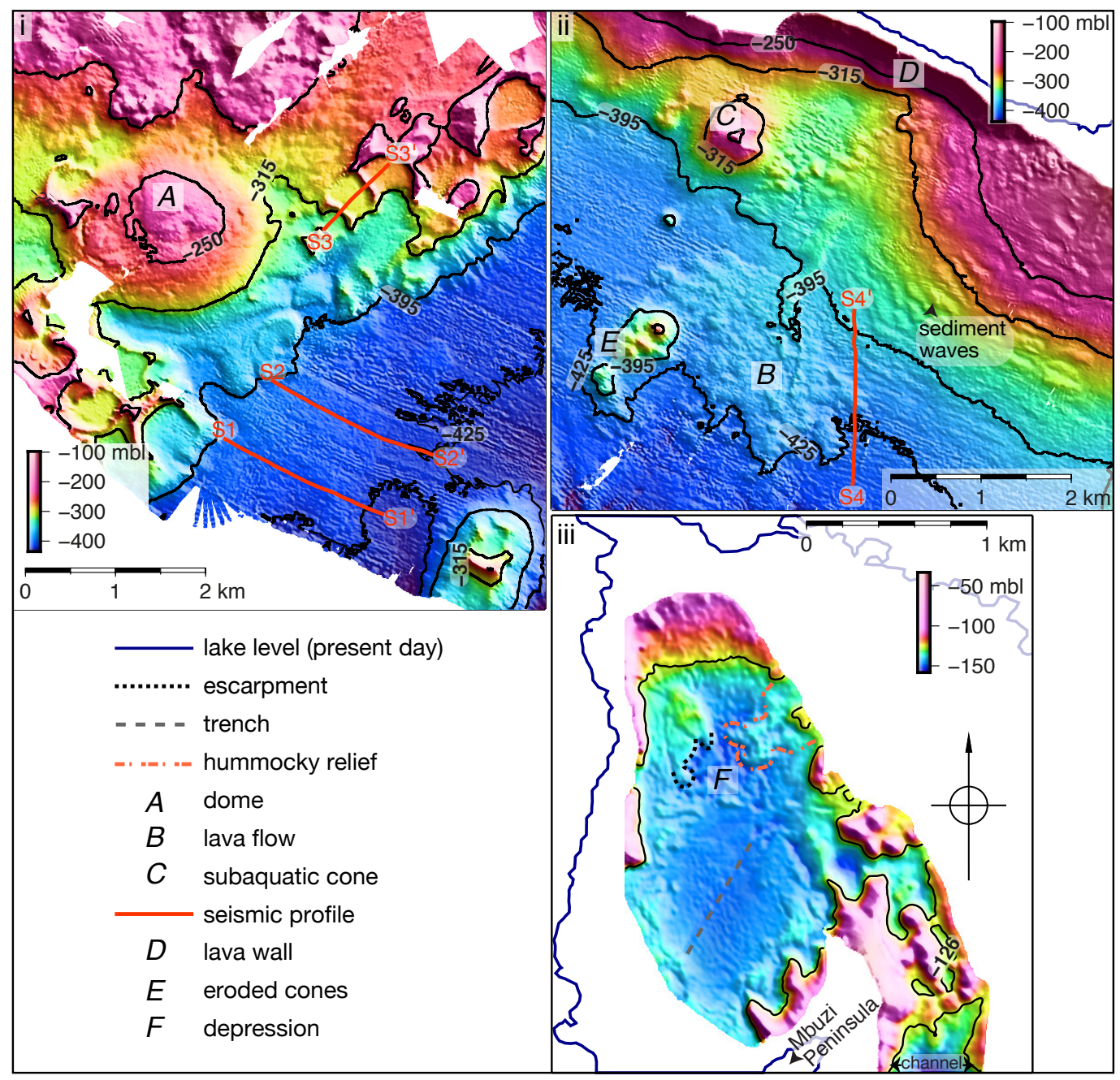

(a) Frames i, ii, and iii from Region 1 in Figure 3 at $5 \mathrm{~m}$ resolution. Features from the morphologic and structural analysis are marked on the map and annotated in the legend. The 250, 315, 395 and $425 \mathrm{~m}$ contours are outlined on each map. The seismic profiles S1 through S6 are depicted in Figure 5. Frame i: The volcanic platform. Frame ii: The submerged flank of Mount Goma with 'sediment waves' along its western margin. Frame iii: The isolated basin connected to the main basin of the lake. The $126 \mathrm{~m}$ contour outlines the height to where warm groundwater fills the basin. The north arrow is found in Frame iii, and the horizontal and water depth scales are located on each frame. 


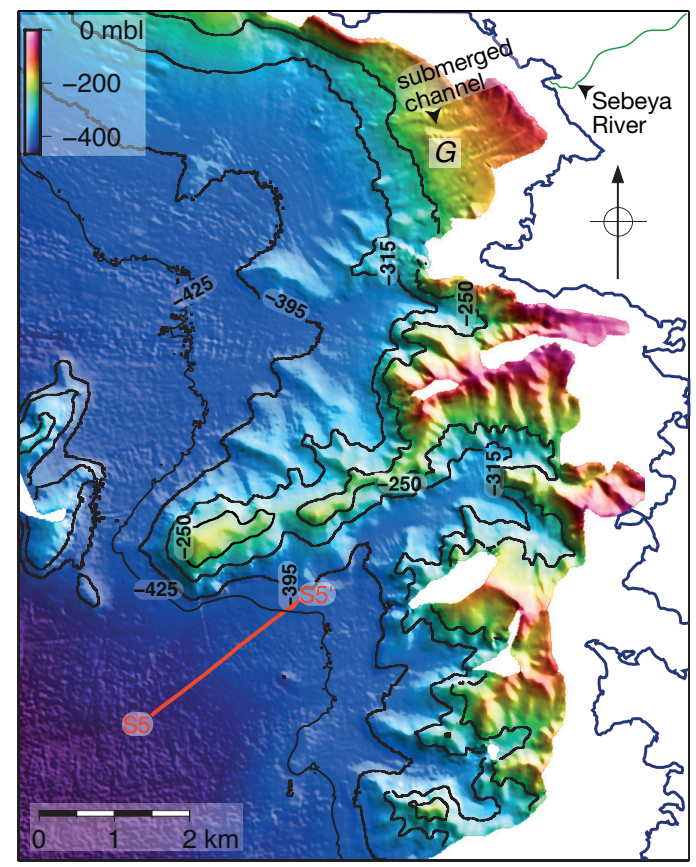

(b) Region 2: The drowned river valleys and delta ' $\mathrm{G}$ '.

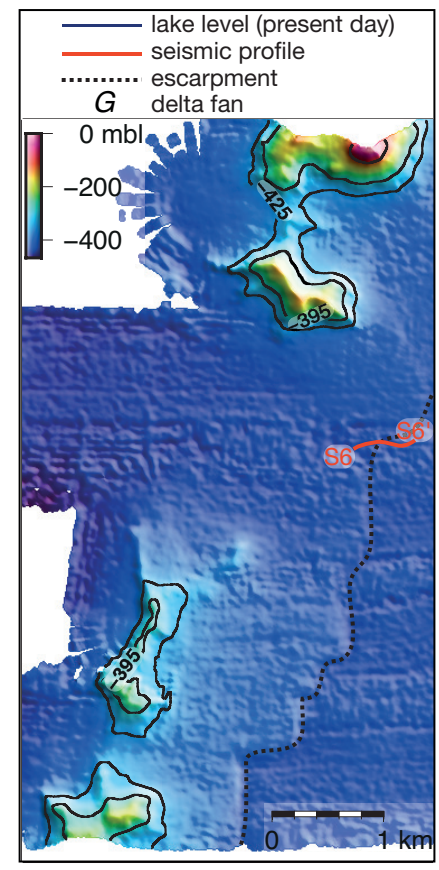

(c) Region 3: Idjwi Island horst structure, outlined by the 'escarpment'.

Figure 4: Region 2 and 3. The north arrow is found in Region 2, and the horizontal and water depth scales are located on each map. The 250, 315, 395 and $425 \mathrm{~m}$ contours are outlined on the maps. The seismic profiles S5 and S6 are depicted in Figure 6. 


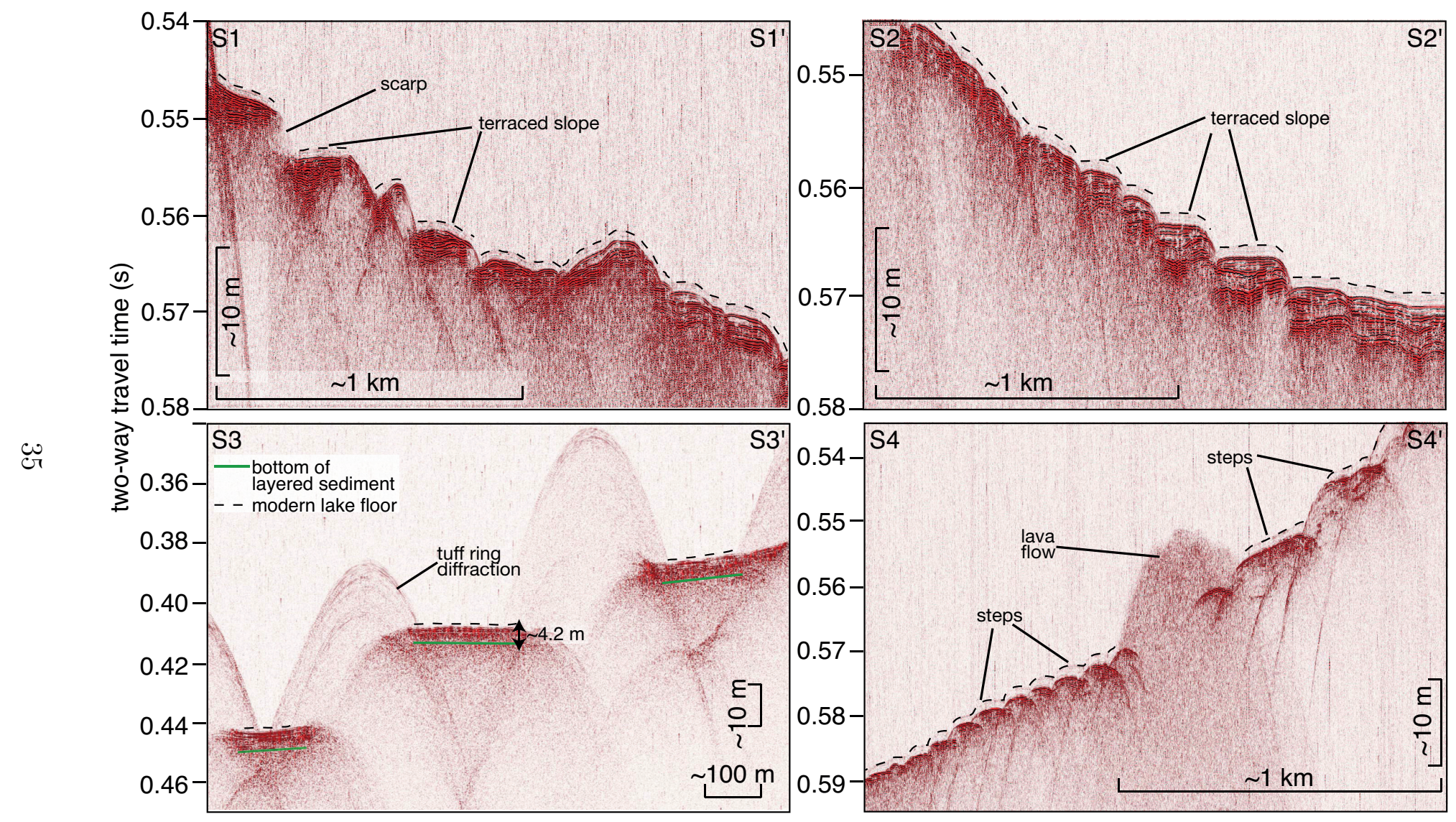

Figure 5: Seismic profiles; S1, S2, S3 and S4, located in Frames ii and iii. The vertical and horizontal scales (in meters) are located in the lower corner of each profile. Annotations are explained within the text. 


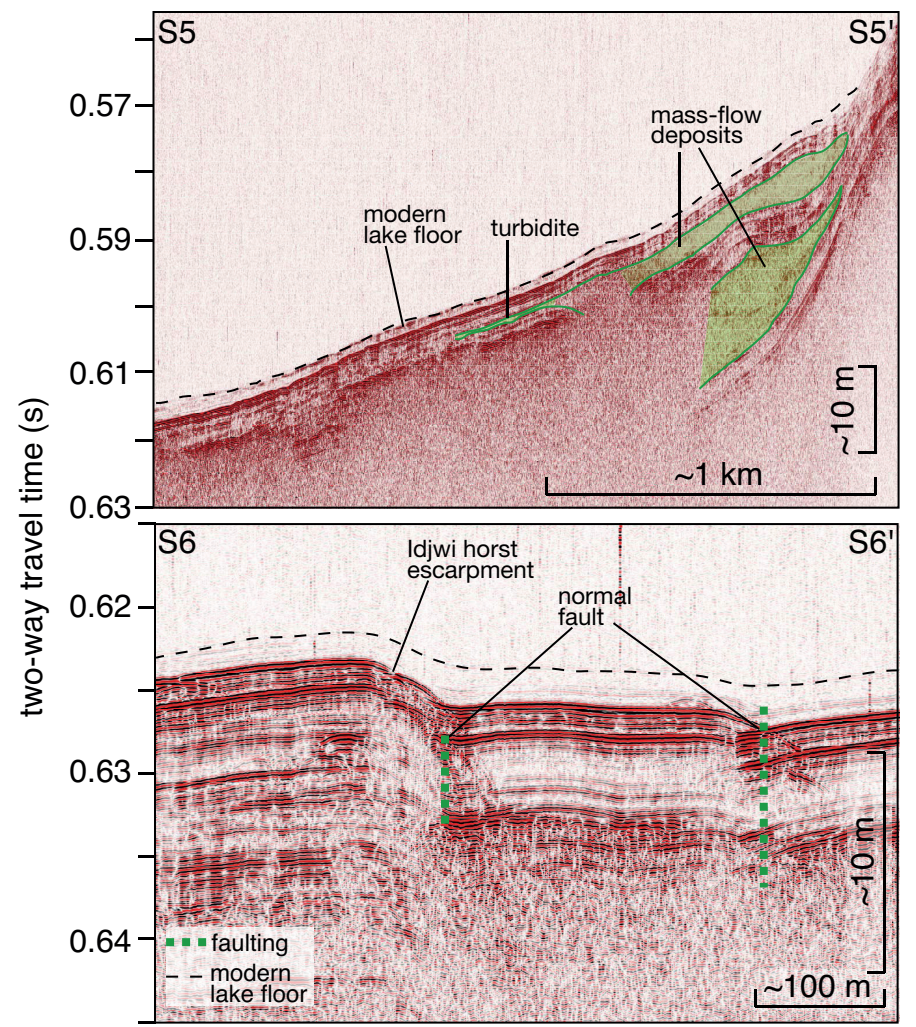

Figure 6: Seismic profiles: S5 and S6, located in Region 2 and 3. The vertical and horizontal scales (in meters) are located in the lower corner of each profile. Annotations are explained within the text. An upper and lower mass-movement observed in the seismic profile S5 are outlined and shaded in green. 